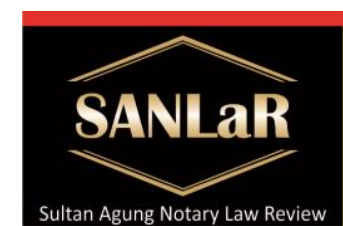

Volume 2 No. 4, December 2020

\section{Sultan Aqung Notary Law Review}

Research on Inheritance for...( Nabilla Ayu Suraya)

\title{
Research on Inheritance for Children from Sirri Marriage Based on the Compilation of Islamic Law
}

\author{
Nabilla Ayu Suraya ${ }^{*}$, Akhmad Khisni ${ }^{* *}$ and Munsharif Abdul Chalim ${ }^{* * *}$
}

*) Student of Master of Notary Law, Faculty of Law, Universitas Islam Sultan Agung (UNISSULA) Semarang, E-mail: ayu539850@gmail.com

$\left.{ }^{* *}\right)$ Lecturer of Master of Notary Law, Faculty of Law, Universitas Islam Sultan Agung (UNISSULA) Semarang

${ }^{* * *}$ Lecturer of Master of Notary Law, Faculty of Law, Universitas Islam Sultan Agung (UNISSULA) Semarang

\begin{abstract}
Sirri marriage is a marriage that is carried out by a couple without notification (registered) at the Office of Religious Affairs (KUA), but this marriage has fulfilled the elements of marriage in Islam, which includes two brides, two witnesses, a guardian, consent, and also the dowry. This marriage Sirri is legal according to religion, but not according to positive law (state law). Inheritance right is a law that regulates that the inheritance of a person who has passed away is given to those who are entitled, such as families and communities who are more entitled. Meanwhile, the inheritance rights obtained by the child resulting from the Sirri marriage can only be obtained from the mother, unless the biological father recognizes and grants the inheritance right which is called wajibat. The research method used is the normative juridical approach, the specification of research by means of an approach that is carried out based on the main legal material by examining theories, concepts, legal principles and legislation related to this research, the data used are primary data and secondary which consists of primary legal materials and secondary legal materials, the data collection techniques used are through library research and field studies. Based on the results of the research, it can be concluded that first, the construction of inheritance rights for children resulting from Sirri marriages based on the Marriage Law, and $\mathrm{KHI}$, children resulting from Sirri marriages only receive inheritance rights in the form of compulsory wills, according to Article 862 to Article 866 of the Civil Code states if the deceased leaves legal descendants, then outside wed children get $1 / 3$ of the share that should be received if they are legitimate children (Article 863 of the Civil Code), inheritance only applies to children outside wedlock who are recognized by the father and/or mother if they are not recognized from father/mother, outside children do not have the right to inherit. Second, the legal consequence of Sirri marriage is that children born out of wedlock or illegitimate are not entitled to inherit from their father. Third, the judge's consideration in deciding the case Number 0177/Pdt.P/2014/PA.Jbg based on the Supreme Court decision Number 46/PUU-VIII/2012 article 43 paragraph 1, namely obtaining the right to demand education financing while according to article 1365 of the Civil Code, civil rights, lineage inheritance, guardian of marriage or any civil rights that are not included in Islamic law are not included in the relationship between father and son that occurs because of a Sirri marriage but can receive a mandatory will. Suggestions before deciding to marry Sirri please think about the many negative impacts behind a Sirri marriage.
\end{abstract}

Keywords: Sirri Marriage; Children; Inheritance Rights. 


\section{Introduction}

Marriage is a physical and mental bond between a man and a woman as husband and wife with the aim of forming a family, a happy and eternal household based on the Supreme Lord. ${ }^{1}$ Islam strongly encourages marriage in various ways. Sometimes by calling it one of the traditions of the prophets and the way of life of the apostles who are leaders whose way of life is followed. ${ }^{2}$

Etymologically, Sirri marriage can be interpreted as a secret or secret marriage. It is said to be a secret marriage because this kind of wedding procession is deliberately hidden from the public for various reasons, and is usually attended only by a limited circle of close relatives, not celebrated in the form of a walimatul ursy reception open to the public.

Sirri marriage is a marriage that is carried out by a couple without notification (registered) at the Office of Religious Affairs (KUA), but this marriage has fulfilled the elements of marriage in Islam, which includes two brides, two witnesses, a guardian, consent, and also the dowry. This marriage Sirri is legal according to religion, but not according to positive law (state law). Therefore, Sirri marriages that are not registered at the Office of Religious Affairs have no legal force, so that if one day they both have problems related to their household such as divorce, domestic violence, inheritance, struggle for child custody and others. the religious affairs office and the religious court cannot decide or even cannot accept complaints from the two of them who are currently having problems. ${ }^{3}$ This model of marriage can usually lead to problems starting from the denial of the occurrence of an illegal marriage and not infrequently the child born in that marriage is also not recognized. Sometimes problems arise in terms of inheritance distribution. ${ }^{4}$

Children born from marriages that are not registered by the competent official have the right to obtain a living and compulsory will from their father and children born in unregistered marriages can apply for child legalization to a religious court, because children have the basic right to know and obtain certainty about who his parents. ${ }^{5}$ However, if it turns out that during his lifetime the father has not given a will to his heirs, then steps can be taken to submit a request for legalization of the child's status to the court.

The status of the child resulting from a unregistered marriage can be recognized by the State as a legal child by submitting an application for ratification to the court. Applications for ratification are generally submitted to legalize the unregistered marriage and the status of the children born from the unregistered marriage. After this ratification, both the wife and children from the marriage can inherit from the deceased party. This legalization determination is necessary for the heirs to obtain a

\footnotetext{
${ }^{1}$ Prodjohamidjojo, Mr. Martiman. (2015). Hukum Perkawinan Indonesia. Jakarta: CV. Karya Gemilang. p. 71.

${ }^{2}$ Sabiq, Sayyid. (2008). Fiqih Sunnah Jilid 2, Penerjemah. Asep Sobari, Jakarta: Al-I'tishom. p. 153.

3 Nasiri, (2010). Praktik Prostitusi Gigolo ala Yusuf Al-Qardawi (Tinjauan Hukum Islam). Surabaya: Khalista. p. 45-46

${ }^{4}$ Shomad, Abdus. (2010). Hukum Islam: Penormaan Prinsip Syariah dalam Hukum Indonesia. Jakarta: Kencana. p. 309.

${ }^{5}$ Supreme Court decision by the Supreme Court Religious Court Commission
} 
Certificate of Inheritance in managing the inheritance of the heir. As well as to provide legal protection for the heir's wife and children, in the eyes of the other heir's family. ${ }^{6}$ The law of inheritance is a law that regulates the inheritance of the assets of someone who has passed away given to those who have the right, such as family and communities who have more rights. ${ }^{7}$.

Compilation of Islamic Law, a collection of Islamic law material written article by article, totaling 229 articles, consisting of three groups of legal material, namely Marriage Law (170 articles), Inheritance Law including wills and grants (44 articles) and Law of Waqf (14 articles). plus one clause of the closing provisions applicable to the three groups of laws.

Due to a dispute about the inheritance rights of unmarried children that occurred in Indonesia, it made me interested in examining more deeply whether the child the result Sirri marriages have the same rights as children resulting from marriages registered by the state.

Based on the description of the background of the problem above, a problem formula can be formulated as follows:

1. How is the distribution of inheritance rights for children resulting from Sirri marriages based on the Islamic Law Compilation?

2. What are the problems that arise with the inheritance rights of children resulting from Sirri marriages and what are the solutions?

3. What is the implementation and consideration of the Judge regarding the inheritance rights for children resulting from Sirri marriages?

\section{Research Methods}

The research method used is the normative juridical approach, the specification of research by means of an approach that is carried out based on the main legal material by examining theories, concepts, legal principles and legislation related to this research, the data used are primary data and secondary which consists of primary legal materials and secondary legal materials, the data collection techniques used are through library research and field studies.

\section{Results and Discussion}

3.1 Inheritance rights of children resulting from Sirri's marriage based on the Compilation of Islamic Law

Islamic inheritance law in effect in Indonesia. In order to ensure orderliness of marriage for the Muslim community, every marriage must be recorded (article 5 verse $1 \mathrm{KHI}$ ). Marriages performed outside the employees of the Marriage Registration Officer, do not have a Marriage Registration (Article 6 paragraph $2 \mathrm{KHI}$ ). Out of wedlock children only have a civil relationship with their mother and their mother's family (Article 43 paragraph (1) UUP in conjunction with Article $100 \mathrm{KHI}$ ). Also

\footnotetext{
${ }^{6}$ https://kantorpengacara.co/hak-mewaris-anak-hasil-dari-perk Marriage-siri/ accessed on January 9 , 2021

7https://id.wikipedia.org/wiki/Hukum waris accessed on January 9, 2021
} 
emphasized by M. Ali Hasan in his book "Inheritance Law in Islam"8that adulterous children only inherit with the family from their mother's side. Compilation of Islamic Law, ${ }^{9}$ does not determine specifically and with certainty about the grouping of types of children as the grouping contained in the Civil Law. In the Compilation of Islamic Law, apart from explaining the criteria for a legitimate child (children born in a legal marriage bond), as stated in Article 99 of the Compilation of Islamic Law, which states that a legitimate child is:

1. Children born in or as a result of a legal marriage.

2. The results of the husband and wife's fertilization outside the womb and born by the wife

Children born outside of legal marriages are known, as stated in Article 100 of the Islamic Law Compilation, that "children born outside of marriage only have a family relationship with their mother and their mother's family". It also explains the status of the child from the marriage of a man with the woman whom he conceived before marriage. As stated in Article 53 paragraph (3) Compilation of Islamic Law: "With the marriage taking place when a woman is pregnant, marriage is not required after the child is born."

Article 75 letter (b) of the Compilation of Islamic Law explains the status of children from a canceled marriage, which reads "the decision to annul a marriage does not apply retroactively to children born from that marriage." Meanwhile, Article 162 of the Compilation of Islamic Law explains the status of Li'an's children. (as a result of the husband's denial of the fetus and/or children that his wife has given birth to).

The position of every child born outside of a legal marriage bond is that of an illegitimate child. Islamic law is in accordance with the Qur'an and Hadiths, still ordaining children out of wedlock to their mothers and relatives.

The Indonesian Ulema Council in its Fatwa issued in May 2006 emphasized that the child resulting from adultery does not have a family relationship, marriage guardian, inheritance, and a living with the man who caused his birth, the child from adultery only has a relationship of lineage, inheritance, and a living with his mother and his mother's family and to provide protection for children outside of wedlock, the Indonesian Ulama Council provides punishment for adulterers in the form of ta'zir, namely by fulfilling the child's life needs, and providing assets after he dies through a mandatory will. The Fatwa also emphasizes that the protection aims to protect the child and not to validate the lineage between the child and the biological father.

\subsection{The result is the child from Sirri marriage}

At present, the portrait of a Sirri marriage is a gloomy portrait of marriage, because in a Sirri marriage it inherits the problems of life that are not simple, to the religious elite who think that Sirri marriage is important because of very strong Islamic thinking, Sirri marriage is one a gloomy portrait and bequeaths ongoing problems to the social impact that is not positive.

\footnotetext{
${ }^{8}$ http://www.hukumonline.com/klinik/detail/cl373/statusanak-haram accessed on 9 January 2021

${ }^{9}$ Article: Status of Children Out of Marriage in Compilation of Islamic Law By: HERIZAL, S. Ag (Penghulu Pada KUA Depati Tujuh Subdistrict)
} 
The consequences of this Sirri marriage are of several kinds, such as the child's lineage, the status of the child and the property itself, here are some definitions of the consequences of the unregistered marriage:

\section{Nasab rights}

The marriage law does not explain in detail regarding the legal birthright of the child, but if we look at the opposite, the child out of wedlock only has compassion for his mother and his mother's family, so we can conclude that a legitimate child has the right to have birth with his father. In accordance with the regulations of the Marriage Law, namely Article 42 Legitimate children are children born in or as a result of a legal marriage. And Article 43 paragraph 1 Children born outside of marriage only have a civil relationship with their mother and their mother's family. Nasab in the doctrinal of fiqh is very urgent, Nasab is the greatest blessing that Allah SWT sends to his servants. Nasab is the legality of kinship based on blood ties, as one of the consequences of a legal marriage. ${ }^{10}$

A person may dedicate himself to someone or his father if he meets the requirements. The conditions are as follows:

a. A child born to a woman is indeed the result of her actions with her husband.

b. When a woman is pregnant, the time is not less than the usual pregnancy time.

c. The husband does not deny the children born to him. ${ }^{11}$

2. Children's rights

Children are obliged to have their rights which must be given from their parents, such as support, maintenance and guardianship, there are several definitions of the child's rights:

a. Living

Legal children must be given by their parents as stated in the Marriage Act No 1 of 1974, which is stated in Article 41:

1) Both mothers and fathers are still obliged to care for and educate their children, solely for the benefit of the children, if there is a dispute regarding the control of the child the Court gives its decision.

2) The father is responsible for all the maintenance and education costs needed by the child, if in fact the father cannot fulfill these obligations. The judiciary can determine that the mother is responsible for these costs.

3) The court may require the ex-husband to provide living expenses and/or determine a portion of the ex-wife's share of the obligation. ${ }^{12}$

b. Maintenance

Globally, the marriage law provides rules regarding the obligations of parents to care for the child, framed in article 45 of the Marriage Law, namely:

(1) Both parents are obliged to care for and educate their children as well as possible

\footnotetext{
${ }^{10}$ ash-Shabuni, Muhammad Ali. (1995). Pembagian Waris Menurut Islam. Jakarta: Gema Insani Press. p. 19.

${ }^{11}$ Dahlan, Abdul azis. (2002). Eksilopedisi Hukum Islam. Jakarta: New Ikhtiar van Hoeve. p. 112.

12 Law of the Republic of Indonesia. (2010). Number I of 1974 concerning Marriage and Compilation of Islamic Law, Bandung: Citra Umara. p. 16.
} 
(2) The obligations of the parents as meant in paragraph (1) of this article shall be valid until the child is married or can stand alone, which obligation continues even if the marriage of the two parents breaks up. ${ }^{13}$

3. Trusteeship

Likewise with the right of guardianship, that the legal child is entitled to be the guardian of the biological parent (father). As stated in Article 47 of the marriage law, namely:

(1) Children who have not reached the age of 18 (eighteen) or have never been married are under the control of their parents as long as their power is not revoked.

(2) The parents represent the child regarding all legal actions inside and outside the court. ${ }^{14}$

4. Property

Based on the decision of the Constitutional Court (MK) Number: 46/PUU-VIII/2010, it states that children born outside of marriage have a civil relationship with their mother and mother's family and with men as their father which can be proven based on science and technology or other evidence who according to the law has blood relations, including civil relations with his father's family. Therefore, the child resulting from a Sirri marriage can obtain inheritance rights from his father if it is proven by science and technology that confirms the child is the father's child.

\subsection{Judge's decision regarding the inheritance rights for children resulting from Sirri marriage}

Based on the Decision of the Supreme Court of the Republic of Indonesia at number: 0177/Pdt.P/2014/PA.Jbg. decided that based on the Decision of the Constitutional Court Number 46/PUU-VIII/2012 dated 17 February 2012, it stated that Article 43 paragraph (1) of Act No 1 of 1974 concerning Marriage (State Gazette of the Republic of Indonesia of 1974 Number 1, Supplement to the State Gazette RI Number 3019) which states that children born out of wedlock only have a civil relationship with their mother and their mother's family, contrary to the 1945 Constitution of the Republic of Indonesia as long as it is interpreted as eliminating civil relations with men which can be proven based on science and technology and/or other evidence according to the law has a blood relationship as the father, So then it must be read that children born outside of marriage have only civil relations with their mothers and their mothers' families, as well as with men as their fathers, which can be proven based on science and technology and/or other evidence that according to the law has blood relations including civil relations with his father's family; Considering, that in order to respond to this provision in relation to the a quo case, the Panel of Judges is of the opinion that the Constitutional Court Decision Number 46/PUU-VIII/2012 dated February 17, 2012 is abstract, so according to the opinion of the Panel of Judges, an inconsistent decision is still needed, therefore the Panel of Judges will consider it further; Considering, whereas observing the decisions of the Constitutional Court as above, It seems that

\footnotetext{
${ }^{13}$ Law of the Republic of Indonesia. (2010). Number I of 1974 concerning Marriage and Compilation of Islamic Law, Bandung: Citra Umara. p. 18.

14 Muhibbin, Abdul Wahid. (2009). Hukum Kewarisan Islam sebagai Pembaharuan Hukum Positif. Jakarta: Sinar Grafika. p. 2.
} 
the amendment to the provisions of Article 43 paragraph (1) if the civil relationship with the mother and the man who impregnated her is understood textually (harfiyah), it can be interpreted as a whole civil law relationship, including those related to Nasab rights, inheritance rights, marriage guardians, and other civil rights. If this happens, it will cause legal confusion, especially for those who are Muslim; Considering, that in the opinion of the Panel of Judges, the amendment to the provisions of Article 43 paragraph (1) in the Constitutional Court decision must be understood in a meaningful way, namely only rights that are not regulated in figh (Islamic law), among others in the form of rights to demand education financing or to demand compensation losses due to unlawful actions that harm others as regulated in Article 1365 of the Civil Code, so that civil rights other than human rights, inheritance rights, marriage guardian,

According to the Religious Court and MUI, the child resulting from a Sirri marriage does not have inheritance rights and only gets a compulsory will. A mandatory will is a will, the implementation of which is not influenced or dependent on the will or will of the deceased person. The will must still be carried out, whether spoken or not, whether desired or not desired by the deceased. Thus, the implementation of the will does not require evidence that the will was spoken or written or desired, but the implementation is based on legal reasons justifying that the will must be implemented.

\section{Closing}

The distribution of the inheritance rights of the children resulting from Sirri's marriage, based on the provisions of the Civil Code, Marriage Law, KHI, Islamic Law, Customary Law in the construction of the law provide different terms and meanings. The term Sirri marriage is found in Islamic law, while in the Marriage Law, KHI, Civil Code and customary law, the term Sirri marriage is identical to marriage under hand. In order to ensure orderliness of marriage for the Muslim community, every marriage must be recorded (article 5 paragraph $1 \mathrm{KHI}$ ). Marriages performed outside the employees of the Marriage Registration Officer, do not have a Marriage Registration (Article 6 paragraph $2 \mathrm{KHI}$ ). Based on the provisions in the $\mathrm{KHI}$, the Islamic inheritance law that applies in Indonesia. In order to ensure orderliness of marriage for the Muslim community, every marriage must be recorded (article 5 verse $1 \mathrm{KHI}$ ). Marriages performed outside the employees of the Marriage Registration Officer, do not have a Marriage Registration (Article 6 paragraph $2 \mathrm{KHI}$ ). Out of wedlock children only have a civil relationship with their mother and their mother's family (Article 43 paragraph (1) UUP in conjunction with Article $100 \mathrm{KHI}$ ).

\section{References}

Books:

[1] Dahlan, Abdul Azis. (2002). Eksilopedisi Hukum Islam, Jakarta: Ikhtiar Baru van Hoeve.

[2] Muhibbin, Abdul Wahid. (2009). Hukum Kewarisan Islam sebagai Pembaharuan Hukum Positif, Jakarta: Sinar Grafika. 
[3] Shomad, Abdus. (2010). Hukum Islam: Penormaan Prinsip Syariah dalam Hukum Indonesia. Jakarta: Kencana.

[4] Herizal, S.Ag. (2006). Hukum Perdata Islam Di Indonesia, Jakarta: Sinar Grafika.

[5] Ash-Shabuni, Muhammad Ali. (1995). Pembagian Waris Menurut Islam, Jakarta: Gema Insani Press.

[6] Prodjohamidjojo, Mr. Martiman. (2015). Hukum Perkawinan Indonesia, Jakarta: CV.

[7] Karya Gemilang.

[8] Nasiri. (2010). Praktik Prostitusi Gigolo ala Yusuf Al-Qardawi (Tinjauan Hukum Islam), Surabaya: Khalista.

[9] Putusan MA oleh Komisi Bidang Peradilan Agama MA.

[10] Sabiq, Sayyid. (2008). Fiqih Sunnah, Jilid 2, Terjemahan Asep sobari, Jakarta: Al-I"tishom .

[11] Undang-undang Republik Indonesia Nomor I Tahun 1974. (2010). tentang Perkawinan dan Kompilasi Hukum Islam, Bandung: Citra Umara.

Internet:

[1] https://id.wikipedia.org/wiki/Hukum waris, Accessed on Saturday 9 January 2021, 14:46.

[2] https://kantorpengacara.co/hak-inherited-child-the result-from-marriage-siri, Retrieved Saturday 9 January 2021, 14:45.

[3] http://www.hukumonline.com/klinik/detail/cl373/statusanak-haram, Accessed on Saturday 9 January 2021, 14:34. 